\title{
Further Study on Implementing Thematic Teaching in Preschool: A Needs Analysis Research
}

\author{
Diani Mardiana Mat Zin, Suziyani Mohamed, Kamariah Abu Bakar, Nurul Khairani Ismail
}

Faculty of Education, Universiti Kebangsaan Malaysia, Selangor, Malaysia

Email:dianimardiana@usim.edu.my

How to cite this paper: Zin, D. M. M., Mohamed, S., Bakar, K. A., \& Ismail, N. K. (2019). Further Study on Implementing Thematic Teaching in Preschool: A Needs Analysis Research. Creative Education, 10, 2887-2898.

https://doi.org/10.4236/ce.2019.1012214

Received: October 21, 2019

Accepted: November 26, 2019

Published: November 29, 2019

Copyright $\odot 2019$ by author(s) and Scientific Research Publishing Inc. This work is licensed under the Creative Commons Attribution International License (CC BY 4.0).

http://creativecommons.org/licenses/by/4.0/

\begin{abstract}
Thematic teaching has been introduced through the Malaysian Preschool Education Curriculum Guidelines (KPM, 1993) since 1993. This research is a preliminary review aimed at looking at the need to conduct further studies on the implementation of thematic teaching and to determine the focus of the research. This research explores the current understanding and practice of eight teachers from eight preschools in Selangor and Negeri Sembilan in implementing thematic teaching. Data collected for this research was based on document analysis, observations, and interviews. Findings of the research show that there were various levels of understanding and methods employed in implementing thematic teaching in the selected preschools. Teachers' understanding is divided into several categories: 1) understanding thematic teaching as curriculum; 2) understanding thematic teaching as an approach; 3) the minimum understanding of thematic teaching; and 4) no understanding of thematic teaching at all. In terms of planning, only two of the teachers integrated thematic teaching in their annual, weekly, and daily lesson plans. The findings on the implementation of thematic teaching also show that teachers: 1) used thematic teaching as the basis of the curriculum;2) applied thematic teaching as one of the teaching approaches; 3 ) used thematic teaching based on the requirements of the teaching and learning; and 4) had not used thematic teaching. This finding supports the need for further research on thematic teaching. A detailed research on the implementation of more practical and friendly thematic teaching for teachers that also fulfills the principles of implementation of such teaching and the overall developmental needs of children should be undertaken.
\end{abstract}

\section{Keywords}

Thematic Approach, Thematic Teaching, Thematic Curriculum, Early 


\section{Introduction}

Children undergo periods of rapid development in their physical, emotional, spiritual, cognitive and social aspects. They learn by interacting with their physical and social environments (Dzainudin, Yamat, \& Yunus, 2018). As such, meaningful social and environmental stimuli are necessary to promote the optimal development of children appropriate to their individual ages, interests, and abilities. Effective, meaningful, and enjoyable preschool learning experiences provide children with the skills, confidence, and positive attitudes in preparation for entry into formal schooling and lifelong education (Rohaty Mohd Majzub, 2003). Mohd Majid Konting \& Mokhtar Haji Nawawi (2009) note that teaching is eased and becomes more effective when appropriate teaching strategies, methods, and practices are used. One of the teaching approaches to promoting children's learning is theme-based teaching. The approach which is based on Appropriate Developmental Practices is also recommended for implementation in the national curriculum in Malaysian preschools (KPM, 1993, KPM, 2010, KPM, 2016). Thematic teaching is an ideal approach for children as it is an integrated curriculum (Driscoll \& Nagel 2008) that integrates a variety of approaches, teacher teaching strategies, subjects, learning goals, children's skills, and development goals in a holistic and balanced way.

\subsection{Thematic Teaching}

Thematic teaching is one of the ways of planning and organizing the implementation of early childhood education curriculum. It is based on managing a curriculum around an idea or topic (Arce, 2000; Driscoll \& Nagel, 2008) that is relevant to the time, place, interests, backgrounds, and level of development of the child (KPM, 2016). Jackman (2001) further explains that this approach focuses on only one theme or topic at a time. This process allows in-depth learning to take place. Thematic teaching is one way of integrating the curriculum as it is a medium that incorporates its various aspects. In conclusion, thematic teaching is a way of managing the curriculum across and incorporating a variety of subjects, teaching techniques, teaching methods, teaching approaches, learning aids, children's activities, and learning spaces organized around a single theme at a time to promote the overall development and skills of children.

Wortham (2006) outlines three strategies for implementing thematic teaching in early childhood education. These strategies are: 1) thematic teaching as the basic framework of the curriculum; 2) thematic teaching as one of the teaching approaches; and 3) thematic teaching as a teaching resource based on the current needs of the activity. Implementing thematic teaching as the basic framework of the curriculum, otherwise known as thematic curriculum, requires teachers to 
design all aspects of the curriculum such as lesson planning, teaching strategy selection, teaching aids, and child-centered learning activities throughout the year. Implementation in this aspect encompasses the entire activity of the children in teaching and learning sessions throughout the day. This strategy requires teachers to make yearly, weekly, and daily planning thematic plans.

The second strategy is to implement thematic teaching as a single approach and is commonly known as the thematic approach. Such a strategy is used where teachers are constrained in designing and implementing thematic teaching for the entire programme as they are bound by existing curriculum requirements. In this situation teachers do not have much opportunity to plan the entire programme and, as such, can still plan the implementation of thematic approaches in a particular subject or activity.

The third strategy for implementing thematic teaching is to use the theme as a learning resource. This strategy is used in the same way as the implementation of the second strategy, which is in the context of the existing rigid curriculum that must be adhered to as a whole and for use by novice teachers who wish to implement thematic teaching in stages. Thematic teaching in this situation is employed when a particular event occurs. For example, celebratory themes are implemented after Hari Raya, holiday themes after school holidays, local fruit themes are implemented during the fruit season, and at other appropriate times.

\subsection{Thematic Teaching in Malaysia}

Malaysian education policy involves gearing early childhood education towards developing human capital through teaching and learning methods that prioritize experiences, active engagement, safety, and enjoyment (KPM, 2016). In practical terms, the policy is translated through the Malaysian National Preschool Standard Curriculum (NPSC) that aims at developing the comprehensive and integrated potential of four- to six-year-olds in the physical, emotional, spiritual, intellectual, and social domains in a safe, nurturing, creative, and meaningful fun-based learning environment (KPM, 1993; 2009; 2016). One of the suggested teaching and learning methods in this strategy is thematic teaching.

Thematic teaching was introduced through the preschool curriculum since 1993 (KPM, 1993). Through this national curriculum, thematic teaching is implemented as one of the teaching approaches. Subsequently, through a review of the curriculum in 2009, the implementation of the thematic approach was improved. In 2010, preschool teaching and learning sessions were conducted through two modules, namely basic modules (comprising language subjects, Islamic education, moral education, mathematics, and outdoor activities) and thematic modules. In general, the basic modules emphasize goals for early literacy in the children's academic skills (reading, counting, writing, and reasoning), Islamic education, and outdoor activities. The basic and thematic modules are provided with separate time allocations that do not involve integrating academic and non-academic skills. Thematic modules are integrated based on a topic or 
theme. The NPSC as revised in 2016, maintained support for thematic teaching in preschools but also emphasized a project-based approach and the implementation of teaching through learning centres.

\section{Problem Statement}

Reflections and improvements are necessary to ensure that the curriculum for early childhood education remains at the optimal level. Nevertheless, Norliah Kasim (2014) states that the national preschool standard curriculum still has room for improvement. Mariani Mohd Nor (2006) notes that learning materials, an environment that stimulates children's learning, appropriate activities, and teachers are important factors in influencing childhood development. As such, managing these factors well will significantly contribute to the optimal overall development of children.

Preschool activities that take into account the holistic development of children using the principles of Appropriate Developmental Practices have not been fully implemented. Teaching and learning methods that are oriented more to the development of academic skills alone have dominated many preschool classes in Malaysia. A number of earlier studies has found that the emphasis of most preschools (Saayah Abu, 2004; Lee, 2005; Bakar, 2009) and parents (Rohaty Mohd Majzub, 2003; Sharifah Nor Puteh, Manisah Mohd Ali, Norshidah Mohd Salleh, \& Aliza Alias 2009; Lu Chung Chin, 2015) are solely on academic achievement to the neglect of children's basic needs through activities which help ensure their balanced development. In preschool teaching and learning, teachers should adopt a variety of approaches in accordance with the principles and practices of child development. Most preschool practices such as summative testing, academic development approaches using workbooks and worksheets, inflexible activity schedules, and high levels of classroom discipline that hinder children's movements do not support Appropriate Developmental Practices that contribute to their development in a holistic manner (Brewer, 2004).

The National Preschool Standard Curriculum recommends the use of a variety of teaching approaches to improve the quality of early childhood education, and one of them is thematic teaching. Thematic teaching is a curriculum-based approach that can serve as a medium for implementing preschool teaching programmes and methods as well as in integrating various learning and skills goals. The strategy of implementing the most effective thematic approach according to Wortham (2006) is to use themes as a basis for the overall curriculum. While implementing thematic teaching as one of the approaches is more difficult to implement and less impactful for children. The strategy of implementing thematic teaching as the basis of the overall curriculum has been widely applied in early childhood education abroad.

Based on the knowledge gaps, lack of thematic teaching understanding, mechanisms of implementation of thematic teaching and the challenges of implementing thematic approaches, researchers have found that there is a need to explore whether further studies on the implementation of such teaching are still 
relevant. As it stands, studies on the implementation of thematic approaches are still lacking in Malaysia (Kon Chon Min, Abdullah Mat Rashid, \& Mohd Ibrahim Nazri, 2012) although their implementation has been recommended in the National Preschool Standard Curriculum since 1993.

\section{Purpose of the Research}

This research is aimed at exploring the implementation of thematic teaching in Malaysia as it has been recommended for the national curriculum since 1993. Further, the findings of this research will justify the need for further research into the implementation of thematic teaching in preschools and help determine the focus of the research.

\section{Methodology}

This research involves qualitative data collection through document analysis, observation, and interviews. Eight teachers from different preschools teaching 5 -year-olds were involved in this study. Two teachers, SP1 and SP2, teaching in government preschool while the other six teachings in non government preschool.

\section{Results}

\subsection{Teachers' Understanding of Thematic Teaching (Table 1)}

Through interviews, all research participants admitted to referring to the NPSC except PK6 who had never used it. PK1, PK2, PK7, and PK8 understood the meaning of thematic teaching. Examples of PK1's words:

'We use the theme ... since morning conversation itself we have already informed the kids about the theme ... after that, for that week we talk about the theme' ... (LATMPK1, 2017)

PK3, PK4, PK5, and PK6 understood themes as topics in children's workbooks used during the teaching and learning sessions. Examples of PK5's words are as follows:

“... yes ... if it's like the themes in the book ..." (LATMPK5, 2018)

Overall, PK1, PK2, PK7, and PK8 had a good understanding of thematic teaching while PK3, PK4, and PK5 only understood the basics of thematic teaching. They understood themes as topics in children's workbooks. PK6, on the other hand, never knew about thematic teaching. PK6 never refers to the national curriculum as he does not have any qualifications in early childhood education. PK3, PK4, PK5, and PK6 did not understand the concept of integration of learning which forms one of the main principles in the implementation of thematic teaching. PK1 and PK2 understood aspects in the integration of learning

Table 1. Usage of NPSC among research participants.

\begin{tabular}{ccccccccc}
\hline Research Participant (PK) & PK1 & PK2 & PK3 & PK4 & PK5 & PK6 & PK7 & PK8 \\
\hline Refer NPSC & $/$ & $/$ & $/$ & $/$ & $/$ & X & $/$ & $/$ \\
\hline
\end{tabular}


but do not apply them because school schedules are designed according to separate learning slots. The study found that only PK7 and PK8 understood and applied the concept of integrated learning as the main principle of thematic teaching. Overall, the study participants' understanding of thematic teaching needs to be improved.

\subsection{Thematic Teaching Planning Practices (Table 2)}

PK1, PK2, PK5, PK7, and PK8 prepared long-term planning (LAADPK1, 2017, LAADPK2, 2019, LAADPK5, 2018, LAADPK7, 2018, LAADPK8, 2019). However, PK5 prepared long-term planning based on the titles of children's workbooks. Only PK7 and PK8 integrated learning areas in long term planning. PK1, PK2, and PK5 had daily planning based on separate learning areas or subjects. PK3, PK4, and PK6 did not create thematic long-term planning (LAADPK3, 2017, LAADPK4, 2018, LAADPK6, 2019). The content of learning is determined entirely by the titles in the children's workbooks. PK4 shows the workbook when requested to view long-term planning, weekly and daily thematic planning.

In terms of weekly planning, PK1, PK2, PK5, PK7, and PK8 prepared thematic weekly plans (LAADPK1, 2017, LAADPK2, 2019, LAADPK5, 2018, LAADPK7, 2018, LAADPK8, 2019). However, only PK7 and PK8 using web themes in weekly planning as suggested by early childhood educators such as Brewer (2004), Jackman (2001, 2009), Wortham (2006), and Driscoll \& Nagel (2008).

In terms of writing a daily planning, only PK1, PK2, PK7, and PK8 included the complete aspects of daily thematic programmes such as themes, subthemes, learning goals, and the developmental domains of the involved children. However, PK1 and PK2 used themes as an approach to divide the teaching and learning sessions into basic and thematic modules that were implemented separately. The basic module is emphasized at the beginning of the school session. The thematic modules on the other hand are only emphasized following the completion of the basic module. In this situation teachers cannot integrate the subjects and skills that children need to master through an activity. PK7 and PK8 planned their teaching and learning process based on thematic activities by integrating all aspects of the curriculum. PK3, PK4, PK5, and PK6 did not formulate a fully-thematic daily planning.

Overall, observations of the teachers' daily planning show that some did not plan their lessons. There were also teachers who were not yet qualified to write daily plans in regard to the planning and implementation of thematic teaching, designing various teaching methods, planning children's activities, designing a variety of teaching aids, and planning the integration of subjects and skills.

\subsection{Implementation of Thematic Teaching (Table 3)}

The findings show that the study participants practiced various ways of implementing thematic teaching. PK1, PK2, and PK5 implemented it as one of the teaching approaches (LAPMPK1, 2017, LAPMPK2, 2019, LAPMPK5, 2018, LATMPK1, 2017, LATMPK2, 2019, LATMPK5, 2018). PK1 and PK2 implemented 
Table 2. Teaching planning practised by research participants.

\begin{tabular}{ccccccccc}
\hline Research Participant (PK) & PK1 & PK2 & PK3 & PK4 & PK5 & PK6 & PK7 & PK8 \\
\hline $\begin{array}{c}\text { Thematic long-term planning } \\
\text { Thematic weekly planning }\end{array}$ & $/$ & $/$ & $\mathrm{x}$ & $\mathrm{x}$ & $/$ & $\mathrm{x}$ & $/$ & $/$ \\
$\begin{array}{l}\text { Thematic daily planning } \\
\text { Them }\end{array}$ & $/$ & $/$ & $\mathrm{x}$ & $\mathrm{x}$ & $\mathrm{x}$ & $\mathrm{x}$ & $/$ & $/$ \\
\hline
\end{tabular}

Table 3. Implementation of thematic teaching practised by research participants.

\begin{tabular}{|c|c|c|c|c|c|c|c|c|}
\hline Research Participant (PK) & PK1 & PK2 & PK3 & PK4 & PK5 & PK6 & PK7 & PK8 \\
\hline Theme as a curriculum basis & & & & & & & I & l \\
\hline Theme as an approach & l & l & & & l & & & \\
\hline Theme based on requirements & & & I & I & & 1 & & \\
\hline
\end{tabular}

the modular curriculum, which is taught through basic modules that focused on academic skills (reading, counting, writing, and reasoning) and thematic modules that focused on the implementation of activities through a planned theme. PK7 and PK8 implemented thematic teaching as the basis of the curriculum (LAPMPK7, 2018, LAPMPK8, 2019, LATMPK7, 2018, LATMPK8, 2019) while PK3 and PK4 used themes only as needed (LAPMPK3, 2017, LAPMPK4, 2018, LATMPK3, 2017, LATMPK4, 2018). PK6 never used themes during the teaching and learning process in their preschools (LAPMPK6, 2019, LATMPK6, 2019).

\section{Discussion}

This study found four categories of participants' understanding of thematic teaching namely, 1) understanding thematic teaching as curriculum, 2) understanding thematic teaching as an approach, 3) understanding thematic teaching at a minimum, and 4) not understanding thematic teaching. The teacher's understanding of a concept is a key factor in the success of any curriculum agenda. Earlier studies have extensively discussed this finding. Many early childhood educators have been unable to implement proposed changes of the National Preschool Standard Curriculum including thematic teaching due to poor teacher understanding. Although having a good understanding of preschool curriculum, they are still unclear on its methodology including the proposed thematic teaching (Sharifah Nor Puteh \& Aliza Ali, 2012). In addition, Abd Salam (2013) noted that they did not have adequate knowledge to practice during teaching and learning session. Teachers' limited understanding of a concept makes it difficult to implement the teaching and learning process (Nutbrown, 2006).

In terms of thematic planning, various methods are used in the planning just as there are many different methods of implementation. Experts suggest that thematic planning begins with a thematic long-term planning (Essa, 2011). To begin with, themes can be planned on a monthly basis and then developed around the interests of the children and teachers. The monthly themes can then 
be refined based on the weekly plan. Early childhood educators suggest thematic weekly plans built using the thematic web (Jackman, 2001, 2009; Brewer, 2004; Wortham, 2006; Kostelnik, Soderman, \& Whiren, 2011). The use of a web-themed mind map makes it easy for teachers to incorporate a variety of subjects, learning goals, children's skills, diverse activities, and other aspects of planning into one space. However, only PK7 and PK8 applied thematic designs as suggested by the experts. According to Dewey, learning becomes more meaningful when the content of learning is planned and integrated with the curriculum and teaching (Wortham, 2006). Norsita (2014) similarly noted that teachers were less skilled in designing teaching.

In the aspect of teaching implementation, various ways of implementing thematic teaching were noted. This result is similar to Wortham's. Wortham (2006) proposes three ways of implementing thematic teaching, namely, 1) theme as the basic medium of the curriculum, 2) theme as one of the learning approaches, and 3) theme as a resource according to need.

PK7 and PK8 implemented thematic teaching in their curriculum as well as the concept of integrated learning throughout the teaching process. Through this strategy, thematic teaching becomes the basis of the overall curriculum implemented in the preschools. The activities related to a theme are planned from the time the children arrive at preschool to when they leave. The thematic-based activities included routine activities (circle time, snack time, mealtimes), learning activities (various teaching strategies, use of various teaching materials, learning space) and outdoor activities (physical activities, free play), and Islamic education. This implementation of thematic teaching as a curriculum base is most effective in providing children with greater opportunities for deeper understanding by linking concepts to learning (Wortham, 2006).

PK1, PK2, and PK5 used thematic teaching as one of the approaches. Such an approach is implemented when a preschool does not practice the thematic teaching as an overall curriculum. Thematic teachings are implemented through specific learning areas, through dedicated slots, or during special events. Thematic teaching as an approach is also conducted in the preschool setting with the existing schedule and planning and teachers have a minimal role in teaching implementation. This implementation strategy is also practiced by government preschool teachers through the NPSC in Malaysia. Nevertheless, Wortham (2006) argues that this strategy is more difficult to implement than the thematic teaching as the basic medium of curriculum implementation.

Participants in other studies applied thematic teaching as a resource according to their needs. This strategy involves the use of minimal themes and is applied to the needs of the teachers' teaching and learning process. In these situations, thematic teaching is not used often. Preschools that emphasize academic development that is not balanced and do not implement Appropriate Developmental Practices tend to use such thematic teaching. This makes it difficult for teachers to integrate thematic teaching through strategies such as using a variety of sub- 
jects, teaching approaches, learning materials, children's activities, and learning spaces.

Apart from the three strategies for implementing thematic teaching, there were also research participants such as PK6 who had never used thematic teaching. The majority of teachers in this preschool had no knowledge of thematic teaching. They did not refer to the national curriculum as the main source for their teaching and learning sessions. In addition, training for the teachers's professionalism development were not well planned by the management of the preschools thus leaving them with little or no pedagogical knowledge.

In the context of government preschool in Malaysia (PK1 and PK2), through a curriculum review in 2010, preschool teaching and learning processes were implemented through two modules, namely basic modules (comprising language subjects, Islamic education, moral education, mathematics and outdoor games) and thematic modules. Generally, the basic module emphasizes goals for early literacy in children's academic skills (reading, counting, writing and reasoning), Islamic education and outdoor games. This means that thematic lessons are taught separately through different special sessions and do not involve integration of academic and non-academic skills. Thematic modules centered around a topic or theme. These include activities for physical, emotional, spiritual, cognitive and social domains of children's development. However, through a revision of the National Preschool Standard Curriculum in 2016, the time allocated for thematic approaches was reduced to allow teachers to implement teaching through project and learning centre approaches. In non government preschool, they have autonomy in implementing teaching and learning activities according to their own curriculum although they are still subject to the national curriculum.

Overall, the findings show that there is diversity in the aspects of understanding, planning, and implementation of thematic teaching in the daily practice of the research participants. However, the most effective strategy for implementing thematic teaching according to Wortham (2006) is to use them as the basis of the overall curriculum. Thematic teaching as one of thematic approaches is more difficult to implement and is less impactful for children. Strategies for implementing thematic teaching as the framework of the overall curriculum have been widely applied in early childhood education abroad as well as been suggested by Jackman (2001, 2009), Brewer (2004), Wortham (2006), Essa (2011), Kostelnik, Soderman and Whiren (2011), and Gestwicki (2014). These diversity results of understanding, planning, and implementation of thematic teaching in this research justify the need for further research on the best practices in thematic teaching. Further, studies on the implementation of thematic teaching are still lacking in Malaysi (Kon Chon Min, Abdullah Mat a Rashid, \& Mohd Ibrahim Nazri, 2012) although thematic teaching has been among the recommendations of the National Preschool Standard Curriculum since 1993. It is hoped that further studies to be undertaken will propose the ideal practices in thematic teaching that are appropriate and relevant to the Malaysian cultural context. 


\section{Conflicts of Interest}

The authors declare no conflicts of interest regarding the publication of this paper.

\section{References}

Abd Salam, K. A. (2013). Penggunaan CBAM Untuk Menilai Pengajaran Guru Dalam Inovasi Kurikulum Prasekolah. Tesis Dr. Fal, Universiti Kebangsaan Malaysia.

Abu, S. (2004). Pelaksanaan aktiviti belajar melalui bermain di tadika-tadika kawasan Melaka tengah, Melaka. http://www.ipislam.edu.my/uploaded/file/saayah.pdf

Arce, E. M. (2000). Curriculum for Young Children: An Introduction. New York: Delmar Cengage Learning.

Bakar, K. A. (2009). Pelaksanaan Aktiviti Permainan Dalam Pengajaran Matematik di Prasekolah di Shah Alam. Master Dissertation, Universiti Kebangsaan Malaysia: Faculty of Education.

Brewer, J. A. (2004). Introduction to Early Childhood Education: Preschool through Primary Grades. Boston, MA: Pearson Allyn \& Bacon.

Chin, L. C. (2015). Pembangunan Dan Keberkesanan Modul Berasaskan Pendekatan Permainan (MBPP). Dalam Pendidikan Awal Matematik Prasekolah. Tesis Dr. Falsafah, Universiti Kebangsaan Malaysia.

Dzainudin, M., Yamat, H., \& Yunus, F. (2018). Emerging Young Children's Thinking through Social and Cognitive Development in the Project Approach. Creative Education, 9, 2137-2147. https://doi.org/10.4236/ce.2018.914155

Essa, E. L. (2011). Introduction to Early Childhood Education: Annotated Student's Edition (6th ed.).

Gestwicki, C. (2014). Developmentally Appropriate Practice: Curriculum and Development in Early Education. Edisi ke-5. Belmont, CA: Wadsworth Cengage Learning.

Huey, L. M. (2005). Satu Kajian Pelaksanaan Aktiviti Permainan di Pusat Prasekolah Swasta Tampoi dan Skudai Negeri Johor. Disertasi Sarjana Pendidikan, Universiti Kebangsaan Malaysia.

Jackman, H. L. (2001). Early Education Curriculum: A Child's Connection to the World (2nd ed.). New York: Delmar Thomson Learning.

Jackman, H. L. (2009). Early Education Curriculum: A Child's Connection to the World (4th ed.). New York: Delmar Thomson Learning.

Kasim, N. (2014). Penilaian Program Transformasi Pendidikan Prasekolah KPM Di Sekolah Kebangsaan (SK). Tesis Dr. Falsafah, Universiti Kebangsaan Malaysia.

Konting, M. M., \& Nawawi, M. H. (2009). Keberkesanan Pengajaran: Kepercayaan Guru Sekolah Rendah tentang Input Pendidikan dan Persekitaran Sekolah. In D. S. M. Daud et al. (Eds.), Pengajaran dan Pembelajaran daripada Pelbagai Perspektif (pp. 115-144). Serdang: Penerbit Universiti Putra Malaysia.

Kostelnik, M. J., Soderman, A. K., \& Whiren, A. P. (2011). Developmentally Appropriate Curriculum: Best Practices in Early Childhood Education. Edisi ke-5. Boston, MA: Pearson.

KPM (1993). Malaysian Preschool Education Curriculum Guidelines. Kuala Lumpur: Kementerian Pendidikan Malaysia.

KPM (2009). Preschool Standard Document. Putrajaya: Bahagian Pembangunan Kurikulum. 
KPM (2016). National Preschool Standard Curriculum. Putrajaya: Bahagian Pembangunan Kurikulum.

LAADPK1 (2017). Document Analysis Report of Study Participant 1. Observation Done on Januari 18, 2017 at Preschool 1.

LAADPK2 (2019). Document Analysis Report of Study Participant 2. Observation Done on Januari 24, 2019 at Preschool 2.

LAADPK3 (2017). Document Analysis Report of Study Participant 3. Observation Done on Januari 10, 2017 at Preschool 3.

LAADPK4 (2018). Document Analysis Report of Study Participant 4. Observation Done on Mac 14, 2018 at Preschool 4.

LAADPK5 (2018). Document Analysis Report of Study Participant 5. Observation Done on November 17, 2018 at Preschool 5.

LAADPK6 (2019). Document Analysis Report of Study Participant 6. Observation Done on January 22, 2019 at Preschool 6.

LAADPK7 (2018). Document Analysis Report of Study Participant 7. Observation Done on November 13, 2018 at Preschool 7.

LAADPK8 (2019). Document Analysis Report of Study Participant 8. Observation Done on February 18, 2019 at Preschool 8.

LAPMPK1 (2017). Report on Observation of SP1 Teacher's Teaching. Observation Conducted on January 18, 2017 at Preschool 1.

LAPMPK2 (2019). Report on Observation of SP2 Teacher's Teaching. Observation Conducted on January 24, 2019 at Preschool 2.

LAPMPK3 (2017). Report on Observation of SP3 Teacher's Teaching. Observation Conducted on January 10, 2017 at Preschool 3.

LAPMPK4 (2018). Report on Observation of SP4 Teacher's Teaching. Observation Conducted on March 14, 2018 at Preschool 4.

LAPMPK5 (2018). Report on Observation of SP5 Teacher's Teaching. Observation Conducted on November 17, 2018 at Preschool 5.

LAPMPK6 (2019). Report on Observation of SP6 Teacher's Teaching. Observation Conducted on January 22, 2019 at Preschool 6.

LAPMPK7 (2018). Report on Observation of SP7 Teacher's Teaching. Observation Conducted on November 13, 2018 at Preschool 7.

LAPMPK8 (2019). Report on Observation of SP8 Teacher's Teaching. Observation Conducted on February 18, 2019 at Preschool 8.

LATMPK1 (2017). Text of Interview with SP1. Interview Held on January 18, 2017 at Preschool 1.

LATMPK2 (2019). Text of Interview with SP2. Interview Held on January 24, 2019 at Preschool 2.

LATMPK3 (2017). Text of Interview with SP3. Interview Held on January 10, 2017 at Preschool 3.

LATMPK4 (2018). Text of Interview with SP4. Interview Held on March 14, 2018 at Preschool 4.

LATMPK5 (2018). Text of Interview with SP5. Interview Held on November 17, 2018 at Preschool 5.

LATMPK6 (2019). Text of Interview with SP6. Interview Held on January 22, 2019 Preschool 6. 
LATMPK7 (2018). Text of Interview with SP7. Interview Held on November 13, 2018 at Preschool 7.

LATMPK8 (2019). Text of Interview with SP8. Interview Held on February 18, 2019 at Preschool 8.

Majzub, R. M. (2003). Pendidikan Prasekolah: Cabaran Kualiti. Syarahan Perdana Universiti Kebangsaan Malaysia.

Min, K. C., Rashid, A. M., \& Nazri, M. I. (2012). Teachers' Understanding and Practice towards Thematic Approach in Teaching Integrated Living Skills (ILS). International Journal of Humanities and Social Science, 2, 273-281.

Nor, M. M. (2006). Realiti Trend dan Isu dalam Pendidikan Awal Kanak-kanak (pp. 81-90). Masalah Pendidikan.

Nutbrown, C. (2006). Key Concepts in Early Childhood Education \& Care. London: SAGE Publications.

Puteh, S. N., \& Ali, A. (2012). Persepsi Guru Terhadap Penggunaan Kurikulum Berasaskan Main Bagi Aspek Perkembangan Bahasa Dan Literasi Murid Prasekolah. Jurnal Pendidikan Bahasa Melayu, 2, 141-159.

Puteh, S. N., Ali, M. M., Salleh, N. M., \& Alias, A. (2009). Penggunaan Dan Pengurusan Bahan Pengajaran Dan Pembelajaran Dalam Kurikulum Permainan Pendidikan Awal Kanak-Kanak. Projek Penyelidikan Geran Peneylidikan Fundamental IPTA (FRGS). UKM-GG-05-FRGS0003-2007. Universiti Kebangsaan Malaysia.

Wortham, S. C. (2006). Early Childhood Curriculum: Developmental Bases for Learning and Teaching. Edisi ke-4. Upper Saddle River, NJ: Pearson Merrill Prentice Hall. 